\title{
THE REMNANT OF MEDIEVAL CHRISTIAN ATTITUDES TOWARDS PROPHET MUHAMMAD: A CRITICAL EVALUATION OF MARGOLIOUTH'S PATHOLOGICAL THEORY
}

\section{Akilu Aliyu Muhammad, Adibah Abdul Rahim**}

*Department of Islamic Studies. Bauchi State University.

KM 18, Azare Zaki Road. Bauchi. Nigeria.

${ }^{* *}$ Department of Usul al-Din and Comparative Religion. Kulliyyah of Islamic Revealed Knowledge \& Human Sciences. International Islamic University Malaysia. 50728. Kuala Lumpur. Malaysia.

Email: **adibahar@iium.edu.my

DOI: https://doi.org/10.22452/afkar.vol21 no2.5

\begin{abstract}
The emergence and expansion of Islam have been considered a severe challenge to Christianity. With its significant expansion, the Christians became so much exasperated. Thus, they started searching for every possible avenue to do away with it. In medieval period, many intellectual and military attacks were launched against Islam. One of the strategies was to create false theories which portrayed Prophet Muhammad (p.b.u.h) negatively. The most absurd theory was 'pathological theory' which attempted to charge him of being epileptic. Although many attempts have been made by both Muslim and some less biased Christian scholars to fish this theory out from the scene, it continues to have relevance even in some of the welllearned contemporary Christian scholar's writings. This study attempts to analyse and evaluate David Samuel Margoliouth's views on this theory since he is one of the well-versed and contemporary Christian scholars. In doing so, analytical, comparative and evaluative approaches have been adopted. The study found that Margoliouth's argument that the Prophet (p.b.u.h) suffered from epilepsy was false and
\end{abstract}


baseless. If the experience of the Prophet (p.b.u.h) was said to be the sign of epilepsy, then the biblical Prophets must also face the same charge since they shared the same physical experiences with the Prophet (p.b.u.h).

Keywords: Christians; epilepsy; Margoliouth; Muslims; Pathological theory; Prophet Muhammad.

\section{Khulasah}

Kemunculan dan perkembangan Islam telah dianggap sebagai cabaran berat kepada agama Kristian. Golongan Kristian menjadi begitu benci dengan perkembangan Islam yang amat ketara. Oleh itu, mereka mula mencari setiap saluran yang mungkin untuk menyingkir dan memburukkan Islam. Pada zaman pertengahan, Islam telah menerima pelbagai serangan intelektual dan ketenteraan daripada golongan Kristian. Salah satu serangan intelektual golongan Kristian terhadap Islam ialah strategi mereka dalam mencipta teori palsu bagi menggambarkan karakter negatif Nabi Muhammad. Teori mereka yang paling tidak masuk akal ialah 'teori pathologi' yang cuba menggambarkan baginda Rasulullah sebagai pesakit epilepsi. Walaupun banyak percubaan daripada golongan Muslim dan juga golongan Kristian yang tidak berat sebelah untuk menangkis teori ini, ia terus menjadi relevan di dalam beberapa penulisan golongan intelek Kristian kontemporari. Kajian ini cuba menganalisa dan menilai pandangan seorang intelek Kristain kontemporari, David Samuel Margalioth mengenai teori epilepsi beliau terhadap Nabi Muhammad. Di dalam kajian ini, penulis mengguna pakai pendekatan analisis, perbandingan dan penilaian terhadap segala hujah. Kajian mendapati bahawa dakwaan Margoliouth bahawa Nabi Muhammad mengalami epilepsi adalah palsu dan tidak berasas. Jika pengalaman Nabi Muhmmad dikatakan sebagai tanda epilepsi, maka para nabi alkitabiah juga dapat dikaitkan dengan pertuduhan yang sama memandangkan mereka juga mengalami 
Akilu Aliyu \& Adibah, "The Remnant of Medieval Christian Attitudes Towards Prophet Muhammad," Afkār Vol. 21 Issue 2 (2019): 141-174

pengalaman fizikal yang sama dengan Nabi Muhammad ketika menerima wahyu.

Kata kunci: Kristian; epilepsy; Margoliouth; Muslim; Teori Patologi; Nabi Muhammad.

\section{Introduction}

Epileptic or pathological theory is used by some Christian scholars, especially, the Orientalists in evaluation of the mental soundness of Prophet Muhammad (p.b.u.h). This theory maintains that he experienced some epileptic fits and suffered from mental disturbance. Whenever it would occur to him, he would assert that it was a divine revelation that came to him. Therefore, according to this theory, the Qur'an, in relation to him, is a product of paranoid delusion, or a product of auditory and visual hallucination.

The theory of epilepsy or pathological theory was first used by the medieval Christians. The most notable of them was Jacob Van Maerlant. ${ }^{1}$ He vehemently argued that the Prophet (p.b.u.h) was epileptic and accused him of telling lies to Khadijah so as to take her mind away from depreciating his quality whenever he fell down of epilepsy. He argued that when one day Muhammad fell down for his epilepsy and Khadijah was watching him, she became conscious that she is married to an unworthy man, but Muhammad persuaded her by telling her that he did not fall down because of epilepsy. It was angel Gabriel (Jibril) that came to him with a revelation from God, and when he saw him he could not bear his brightness, so he fell down. ${ }^{2}$ Maerlant claimed that, that is how Muhammad used to do to make Khadijah as well as other people to believe him. ${ }^{3}$

\footnotetext{
${ }^{1}$ Jacob Van Maerlant, quoted from Geert H. M. Claassens, "Jacob Van Maerlant on Muhammad and Islam," in The Medieval Christian Perceptions of Islam, ed. by John Victor Tolan (New York: Garland Publishing, Inc. 1996), 219.

${ }^{2}$ Ibid., 220.

${ }^{3}$ Ibid.
} 
John of Damascus was also among the earliest medieval polemicists who attacked Prophet Muhammad on epilepsy. He even argued that through Muhammad's marriage with Khadijah he had not only secured relaxation and riches but he had also known how to hide his epileptic attacks. ${ }^{4}$ In the contemporary period, this theory continues to be used by most of the Christian scholars. The most famous among them is David Samuel Margoliouth. He confirmed that the Prophet (p.b.u.h) suffered from epilepsy. Before embarking on exploration and evaluation of his views on this theory, it is important to shed light on his historical and intellectual backgrounds.

\section{Historical and Intellectual Backgrounds of David Samuel Margoliouth}

Analysis and evaluation of any intellectual scholar's contributions could not be properly carried out if his intellectual backgrounds are not thoroughly and meticulously explored. To avoid premature and impromptu analysis and appraisal, searching for and exploring the surrounding circumstances, internal and external influences and various experiences which equipped him to attain such a level of scholarship are not only important, but also pivotal and inevitable. To search for those grounds is to search for the nature and level of his scholarship. If the nature and level of his scholarship are properly and accurately discovered, analysis and evaluation of his works would be rightly conducted.

Hence, this segment is dedicated to carry out such an assignment. The main aim therefore is to equip the researcher with some essential tidings which may enable him to objectively evaluate the various views and ideas of David Samuel Margoliouth towards the Prophethood of Muhammad (p.b.u.h) and revelation of the Qur'an.

4 Minou Reeves, Muhammad in Europe (New York: New York University Press, 2003), 8. 
Akilu Aliyu \& Adibah, "The Remnant of Medieval Christian Attitudes Towards Prophet Muhammad," Afkār Vol. 21 Issue 2 (2019): 141-174

\section{His Personal and Social Backgrounds}

On $17^{\text {th }}$ October 1858, Ezekiel Margoliouth and Sarah Iglitzki welcomed their child David Samuel Margoliouth in London. He was said to be the only son to his parents. His father and father's uncle, Moses Margoliouth (1818-81), were said to have converted from Judaism to Anglicanism. ${ }^{5}$ The former was said to have worked in Bethnal Green as a missionary to Jews $^{6}$ while the latter was said to be a renowned scholar in Biblical studies who published The Fundamental Principles of Modern Judaism (1843) and many other works, and between 1877 and 1881 served as vicar in Little Linford, in Buckinghamshire. ${ }^{7}$

Therefore, David Samuel Margoliouth could be said to be a Jew by origin and the product of Jewish converts to Christianity. His family was incredible in England not only for converting to Christianity but for the leaders it provided for the missionary movement in that community. ${ }^{8}$

However, Margoliouth was ordained to the Anglican ministry as deacon and priest in 1899 in Liverpool Cathedral. ${ }^{9}$ He worked as an examining chaplain to the bishop of Liverpool for the period of four years after his ordination. He used to deliver sermons which were said to be grounded in the evangelistic tendencies, and this attracted many audiences to his preaching. ${ }^{10} \mathrm{He}$ married on 25th April, 1896. His wife, Jessie Payne Smith (18561933) ${ }^{11}$ was a daughter of a renowned Syriac scholar, Dean

5 H. C. G. Matthew and Brian Harrison ed. Oxford Dictionary of National Biography, vol. 36 (Oxford: Oxford University Press, 2004), 658.

${ }^{6}$ Ibid.

${ }^{7}$ The Concise Dictionary of National Biography From Earliest Time to 1985, vol. 11 (Oxford: Oxford University Press, 1997): 1947.

${ }^{8}$ Stefan C. Reif, A Jewish Archive from Old Cairo: The History of Cambridge University's Genizah Collection (New York: Routledge, 2000), 96.

${ }^{9}$ Oxford Dictionary of National Biography, 661.

${ }^{10} \mathrm{Ibid}$.

${ }^{11}$ Ibid. 
of Canterbury, Dr. R. Payne Smith. ${ }^{12}$ Although they were not blessed with a single child, it is said that they lived happily and cared for each other. The death of Jessie in 1933 was an irrecoverable wound in his mind. After her death, one of her nieces continued keeping the house for him until when he was moved into a London nursing home and died on $22^{\text {nd }}$ March 1940 in the Middlesex Hospital. ${ }^{13}$

\section{His Academic Background}

In the early years of his life, Margoliouth attended Hackney collegiate school and won a scholarship to Winchester collegiate in $1872 .{ }^{14}$ In the year 1877, he got another scholarship and joined New College, Oxford. Margoliouth was talented during his studies and he was said to be the first-class student. He won many awards and scholarships. He got Hertford and Ireland awards in the year 1878. In 1879 he got Gaisford prize for Greek prose, and in the same year he got a senior Kennecott award. In the year 1880 he got the Houghton Syriac prize. In the year 1881 he got Crave award, and in the same year the Boden Sanskrit scholarship was granted to him. In the year 1882 he got Derby awards, and in the same year the Kennicott Hebrew scholarship was given to him.

About a year after his graduation, Margoliouth's educational talent enabled him to become a fellow in the college from which he graduated, New College, Oxford. ${ }^{15}$ In the year 1889 he was assigned the Laudian professor of Arabic and maintained the chair until 1937 when he became extremely sick. ${ }^{16}$ Margoliouth specialized in Arabic studies,

\footnotetext{
12 Arthur Jeffery, "David Samuel Margoliouth", The Muslim World, vol. 30, no. 3, (1940), 295.

${ }^{13}$ Oxford Dictionary of National Biography, 661.

${ }^{14}$ Ibid., 658.

15 Ibid., 659.

${ }^{16}$ Arthur Jeffery, “David Samuel Margoliouth”, 295.
} 
commentary on Aristotle's works and Islamic history. ${ }^{17} \mathrm{He}$ was seen as a polymath whose scholarship in oriental studies was unparalleled in his generation within the British orientalism. ${ }^{18}$

Throughout his academic journey, Margoliouth was associated with the Royal Asiatic Society. He became its director in the year 1924, and from 1934-1937 he served as its President. He was awarded the society's Gold Medal in the year 1928 in honour of and respect for his scholarship and enormous contributions to the society. In addition, Margoliouth served as a corresponding member of many societies. His proficient scholarship enabled him to be given fellowship of the British academy for a long time under whose sponsorship he delivered Schweich Lectures on 'The relations between Arabs and Israelites Prior to the Rise of Islam' in the year 1921. ${ }^{19}$ In the year 1934 he became an honorary member of the German Oriental Society. He was also made an honorary member of the American Oriental Society in the year 1937. ${ }^{20}$

Moreover, like most of the orientalist scholars, Margoliouth also travelled widely for teaching and intellectual purposes. He was said to have travelled to Cairo and Baghdad and delivered some very wonderful and successful lectures in Arabic language. He also visited India twice and delivered lectures on Islam at the University of Panjab (former name of Punjab) in 19161917, and also at the Universities of Bombay (former name

17 Merriam Webster, Webster's New Biographical Dictionary (Massachussets: Merriam Webster, 1988), "Margoliouth, David Samuel" 653.

${ }^{18}$ Edward Ullendorff, "Alfred Felix London Beeston", in A Century of British Orientalists 1902-2001, edited by C. Edmund Bosworth (New York: Oxford University Press, 2001), 55.

${ }^{19}$ Arthur Jeffery, “David Samuel Margoliouth”, 297.

${ }^{20}$ Ibid. 
of Mumbai) and Calcutta (former name of Kolkata) in 1929. ${ }^{21}$

\section{Margoliouth's Expertise in Arabic and other Classical Languages}

Despite the fact that Margoliouth was a self-taught scholar in Arabic, ${ }^{22}$ he became well-versed and erudite in that field. His expertise first appeared after his study of the Arabic version of Aristotle's poetics which was issued in the year 1887. ${ }^{23}$ His knowledge of Arabic was not academically known because his academic dossier showed that he was expert in two areas only, Hebrew and Syriac. After the death of the Laudian professor of Arabic, Robert Gandell in 1887, the chair remained vacant for some years because there was no capable scholar to hold it. When Margoliouth submitted his file for nomination, it became strange for the University's electoral board because it did not show any qualification related to Arabic. But eventually he succeeded and became the next Laudian professor of Arabic.

However, Margoliouth considered this position as an ample opportunity for him to present his proficiency in Arabic to the world and prove his entitlement to this appointment. It can be seen that within a period of five years he produced some illustrative and controversial scholarly publications in Arabic which proved him to be well-informed in that field and capable of holding the chair that he was entrusted to. He remained Laudian professor for forty-eight years. H. A. R. Gibb points out that:

"In the years following his appointment to the Laudian Chair in 1889, a series of erudite publications, the Arabic papyri at the Bodkeian Library (1893), a translation of part of Baidhawi's Koran-Commentary (1894), and the

\footnotetext{
${ }^{21}$ Ibid.

22 Frederick Quinn, The Sum of All Heresies: The Image of Islam in Western Thought (Oxford: Oxford University Press, 2007), 142.

${ }^{23} \mathrm{Ibid}$.
} 
Letters of Abul-'Ala (1898) testified his mastery of the most difficult and intricate branches of Arabic literature." 24

Margoliouth also served as a translator and editor of Arabic writings. This exercise, once again, was a clear indication of his adept scholarship in Arabic. This might be the ground for Gibb's argument that:

"It was in editing and translating Arabic texts that Margoliouth's scholarship found its most congenial field...As a translator he combined scrupulous accuracy with ease of diction..." 25

Due to his vast knowledge in the field of Arabic studies, he was said to be among the few non-Arab scholars to be elected as a member of the Arabic Academy of Damascus when it was founded in $1920 .{ }^{26} \mathrm{He}$ was also said to be among the few competent Arabic scholars who engaged in papyrology in which he wrote the Arabic Papyri of the Bodlein Library in 1893 and those of the Rylands Library at Manchester in 1933. ${ }^{27}$

His article The Origins of Arabic Poetry (1925) published in The Journal of the Royal Asiatic Society is one of the most controversial articles in orientalist scholarship on Arabic studies. In the article, Margoliouth asserted that pre-Islamic Arabic poetry is a fabrication of later Muslim scholars so as to claim and establish the miraculous nature of the Qur'an.28

Moreover, apart from his mastery of Arabic, Margoliouth was said to have mastered other languages.

${ }^{24}$ H. A. R Gibb, Obituary Notice "David Samuel Margoliouth", Journal of the Royal Asiatic Society, vol. 72, no. 4, (July 1940), 392.

${ }^{25}$ H. A. R Gibb, Obituary Notice "David Samuel Margoliouth”, 393.

${ }^{26}$ Arthur Jeffery, "David Samuel Margoliouth", 297.

${ }^{27}$ Ibid., 296.

${ }^{28}$ For detailed discussion see Margoliouth, "The Origins of Arabic Poetry," The Journal of the Royal Asiatic Society, vol. 57 no. 3 (1925), 417-449. 
Although he had some defect in his enunciation when speaking whatever language including English, his mother tongue, his mastery of languages is remarkable and undeniable. ${ }^{29}$ His first interest, it is said, was in classical languages. He was among the remarkable and great British scholars of Greek language, and his written verses in both Latin and Greek were sufficient to demonstrate his proficiency in and mastery of those languages.

His academic dissertation which was published in 1888 was Analecta Orienta ad Poeticam Aristoteleam. Besides Greek and Latin, he was also said to be expert in Syriac, Turkish, Armenian and Persian. When his wife's father Dr. Payne Smith died it was he and his wife who completed the compendious Syriac dictionary which he started. Margoliouth's works on Syriac and Armenian studies were mostly in the form of monographs and papers. ${ }^{30}$

\section{His Expertise in Islamic Studies}

Margoliouth's expertise in and contributions to the field of Islamic studies cannot be overemphasized. Despite the fact that he was expert in other fields, he appeared to be more interested in Islamic studies and Arabic in which his contributions were immense. He wrote a considerable number of books in the field. His writings led some scholars to assert that he was more knowledgeable in Islamic studies than most of the Muslim scholars. ${ }^{31}$

However, in the year 1905, Margoliouth published Mohammed and the Rise of Islam. Six years later, in the year 1911, he published another work entitled Mohammedanism. In the year 1914, he published another important series of his Hibbert Lectures on the Early Development of Mohammedanism. It was asserted that

\footnotetext{
${ }^{29}$ Arthur Jeffery, "David Samuel Margoliouth”, 295.

${ }^{30}$ Ibid., 295-296.

${ }^{31}$ The New Encyclopedia Britannica, 15th edition, "Margoliouth, David Samuel." 383.
} 
these three significant books served as Standard English treatises on Islamic history for at least a generation. In the year 1924 his Schweich Lectures on 'Relations between Arabs and Israelites Prior to the Rise of Islam' was also published.

With the appearance of those writings, especially Mohammed and the Rise of Islam (1905), Margoliouth appeared as a controversial interpreter of Islam. However, by observing his writings, it may be argued that Margoliouth is one of the bitter enemies of Islam. Although he possessed considerable knowledge on Islam from its original sources, he preferred to view it from negative viewpoint. Humayun Ansari pointed out that:

"While Margoliouth had many things good to say about Muhammad and Islam, he considered Muhammad and his followers to be ultimately deeply flawed in several respects." ${ }^{2}$

It can be observed that Margoliouth in his discussion on Islam was influenced by the methods and ideas of many other orientalists. In most cases, he quoted Ignac Goldziher (1850-1921), Theodor Noldeke (1836-1930), Julius Wellhausen (1844-1918), Sir William Muir (1819-1905), Aloys Sprenger (1813-1893) and many others. That might be the reason for the appearance of their relics in his various writings. For example, he shared the same idea with William Muir in portraying Prophet Múlammad (p.b.u.h) as epileptic. He also subscribed to Ignac Goldziher's methodology in rejecting the traditions of the Prophet (p.b.u.h).

\section{Some of His Various Works}

Margoliouth's various contributions in academia earned him not only reputation among the Muslim and non-

${ }^{32}$ K. Humayun Ansari, "British Historical Imaginations: Rethinking Orientalism?," in Orientalism Revisited: Art, Land and Voyage edited by Ian Richard Netton (New York: Routledge, 2013), 24, Note 64. 
Muslim scholars, ${ }^{33}$ but he was even considered to be and listed among the most eminent scholars ever existed on the earth. ${ }^{34}$ Throughout his academic career, he produced prolific and significant treatises in Hebrew, Syriac, Arabic and Islamic history. Most of his writings are highly controversial.

His natural gift in academia instilled in him arrogance and whenever he was criticized by any scholar, he would try to show his prodigy and brilliance. However, among his remarkable works that demonstrate his vastness and aptitude in the academia are as follows:

1. A Commentary on the Book of Daniel (1889)

2. An Essay on the Place of Ecclesiaticus Semitic Literature (1890)

3. Arabic Papyri of the Bodleian Library (1893)

4. Chrestomathia Baidawiana: The Commentary of elBaidawi Sura III (1894)

5. Lines of Defence of the Biblical Revelation (1900)

6. Religions of Bible Land (1902)

7. A Compendious Syriac Dictionary (with his wife Jessie Payne, 1903)

8. On the Origin and Import of the Names Muslim and Hanif (1903)

9. The Synoptic Gospels as Independent Witnesses (1903)

10. Mohammed and the Rise of Islam (1905)

11. Umayyads and 'Abbasids (1907)

12. The Kitab al-Ansab of al-Sam'ani (1911)

13. The Poetics of Aristotle (1911)

14. Mohammedanism (1912)

15. On Moslem Tradition (1912)

16. The Early Development of Mohammedanism (1914)

${ }^{33}$ The New Encyclopedia Britannica "Margoliouth," 838.

34 Universal Encyclopedia of the Most Eminent Men and Women from Earliest Time to the Close of Nineteenth Century, "Margoliouth, David Samuel.”, 536. 
Akilu Aliyu \& Adibah, "The Remnant of Medieval Christian Attitudes Towards Prophet Muhammad," Afkār Vol. 21 Issue 2 (2019): 141-174

17. The Chronograms of the Euripidean Dramas (1915)

18. Yaqut's Dictionary of Learned Men, 7 volumes (1908-1927)

19. The Table-talk of a Mesopotamian Judge, 2 volumes (1921-1922)

20. The Eclipse of the Abbasid Caliphate (1922)

21. The Homer of Aristotle (1924)

22. The Relations between Arabs and Israelites Prior to the Rise of Islam (1924)

23. Textual Variations of the Koran in the Muslim World (1925)

24. The Origins of Arabic Poetry (1925)

25. Lectures on Arabic Historians, delivered before the University of Calcutta, February 1929

26. South Arabia and Islam (1929)

27. Byzantine Series (1930)

28. Harut and Marut in the Muslim World (1930)

29. Ideas and Ideals of Islam (1930)

30. To the British Reader (1931)

31. Is Islam a Christian Heresy? (1933)

32. The Relics of the Prophet Muhammad (1937)

33. Mohammed (1939)

\section{Margoliouth's on Prophet's Psyche}

This segment of the research is an attempt to carry out a critical analysis and evaluation of Margoliouth's argument that Prophet Muhammad (p.b.u.h) was epileptic. Before carrying such a task, it may be imperative to shed some light on the meaning and concept of epilepsy. This, it is hoped, may help to clearly identify and explain Margoliouth's points which caused him to portray the Prophet (p.b.u.h) as having experienced epileptic fits while receiving the revelation of the Qur'an.

\section{The Meaning and Concept of Epilepsy}

Epilepsy is seen as, sudden and recurrent disturbances in mental function, state of consciousness, sensory activity or movements of the body caused by paroxysmal malfunction 
of cerebral nerve cells. ${ }^{35}$ It is seen as one of the terribly nervous disorders with highest prevalence rates in early childhood and old age. ${ }^{36}$ Epilepsy is often accompanied by convulsion which causes sudden unconsciousness, failing and shaking of limbs. Other symptoms include strange and unusual behaviours, nostalgic imagination, hallucinatory visions and changes in attitudes. ${ }^{37}$

Epilepsy is characterized by recurrent seizures. In some type of the seizures, as in temporal lobe epilepsy or complex partial seizure, conscious contact with the surroundings is lost, and the patient may not know what is happening around him. ${ }^{38}$ Although in most cases there are no symptoms between the seizures, the epileptic may experience an aura shortly before the seizure occurs. Sometimes during illness, trauma, tension and pressure, the seizure may occur. ${ }^{39}$ During the seizures, mostly, the epileptic person bites his tongue, feels sleepy and becomes confused and unconscious. However, the hitches and problems of seizure caused by epilepsy are not only injuries but also mental disorders such as depression. ${ }^{40}$

\section{Analysis of Margoliouth's Views on Prophet's Psyche}

The old inherited pathological theory which claimed that Prophet Muhammad (p.b.u.h) suffered from epilepsy gets relevance in Margoliouth's treatises on him. He argued that the claim which is current in various Christian writings that the Prophet was epileptic gets remarkable confirmation in the experiences which he came across during the process of the revelation.

\footnotetext{
35 The New Encyclopaedia Britannica, "epilepsy”, 525.

${ }^{36}$ Bettina Schmitz, "Epilepsy," in the Encyclopaedia of Human Brain, ed. V.S. Ramachandram (New York: Academic Press, 2002), 201.

${ }^{37}$ The New Encyclopaedia Britannica, "epilepsy”, 525.

${ }^{38}$ Illustrated Medical Dictionary, $1^{\text {st }}$ edition, "epilepsy”, 206.

${ }^{39} \mathrm{Ibid}$.

${ }^{40}$ Schmitz, "Epilepsy," 202.
} 
However, according to this assertion, if the Prophet's experiences during the revelation are to be critically examined, it will be clear that he experienced epileptic fits. These fits, Margoliouth elaborated, are the fit of unconsciousness which is usually accompanied by the bell's sound in his ears, or the hallucinatory vision that an absent person is present, or a seizure which usually causes patient to sweat, or the turning of someone's head to one side or producing frothy saliva from the mouth, or by turning of the face into white or red and by suffering from headache. ${ }^{41}$ Moreover, he continued to claim that ${ }^{42}$ :

"We have already seen reason for believing that Mohammed at some time had epileptic fits... The process described, at times accompanied by snoring and reddening of the face presently came to be recognized as normal form of inspiration..."

Margoliouth firmly believed that Prophet Muhammad (p.b.u.h) experienced all those fits during the process of the revelation and these are the symptoms of epilepsy. But the signs of severe epilepsy like gradual collapse of the brain power, biting of the tongue and throwing down what is in the hand, he said, are missing. ${ }^{43}$

Moreover, he connected the death of Prophet's children with the medical problem which he considered, as we may think, to be the side effect of epilepsy. He argued that his sons died when they were infants and the girls did not live longer and the most long-lived one did not even reach her fortieth year. As regard to this, he argued, "some who understand medicine have drawn their inferences about their father". ${ }^{44}$ How did he medically come to this

\footnotetext{
${ }^{41}$ David Samuel Margoliouth, Mohammed and the Rise of Islam (New Delhi: Cosmo Publications, 2011), 45-46.

${ }^{42}$ Ibid., 85-86

${ }^{43}$ Ibid., 46.

${ }^{44}$ Ibid., 69.
} 
conclusion? He did not mention. His reader, of course, may ask why such an eminent scholar would suggest such an argumentative theory without providing supporting details.

Evaluation of Margoliouth's Views on Prophet's Psyche

\section{His Evidence}

Although Margoliouth did not provide any clear evidence; neither logical nor scientific to support his claim, it may be assumed that he relied on some traditions dealing with the Prophet's physical experiences at the time of revelation.

\section{Implication of His Assertion}

It appears that Margoliouth came to his hasty and unscientific conclusion that the Prophet (p.b.u.h) was epileptic based on the physical experiences which he used to undergo when receiving the revelation. Those experiences, Margoliouth assumed, were the signs of epilepsy and therefore he was epileptic. Since he was mentally imbalanced his Prophethood was not authentic and his revelation was not truly divine.

\section{Refutation}

As has been pointed out earlier, the claim that Prophet Muhammad (p.b.u.h) suffered from epilepsy was among the earliest unsubstantiated false theories which were developed and promoted by the Christian scholars; who intended to accuse the Prophet of suffering from "a paroxysm of cataleptic insanity" 45 as a result of which the Qur'an came into existence. This claim was meant to ridicule, amuse and finally reject the authenticity of the Qur'an.

\footnotetext{
45 The above words which have been put in the inverted commas are the exact words used by Sprenger in his charge against the Prophet (p.b.u.h) of being mentally sick. See A. Sprenger, Life of Mohammad from Original Sources (Allahabad: Presbyterian Mission Press, 1851), 114.
} 
Margoliouth's subscription to and advocacy of this claim without any medical conclusion; despite his acclaimed scholarship in the field of Islamic studies, may lead his reader to question his sincerity. This lacuna, as can be seen clearly in his discussion, is such a slipshod which is unforgivable in the academia. It is uncompromisingly unacceptable to draw such a controversial, and of course, provocative medical conclusion which is seriously connected with theological issues based on untenable assertions.

However, since the main evidence for this assertion lies on the Prophet's state of affairs during the revelation, the narrations dealing with such a state of affairs or experiences will be discussed in detail in order to find out as to what extent such a claim could be divergent or convergent with the real happenings in the Prophet's biography.

\section{Prophet's Physical Conditions during the Revelation: Analysis of Islamic Data}

Although the Qur'an outlines clearly the ways of the revelation, ${ }^{46}$ it does not explicitly mention the experiences which the Prophet (p.b.u.h) would or used to go through while receiving the revelation. But it may be inferred that there is an indication in the Qur'an itself that he received the revelation in hard and difficult conditions. This inference may be drawn from the verse in which Allah says, "We shall, indeed, send down to you a weighty word (qawlan thaqìlā)". ${ }^{47}$ The phrase qawlan thaqìlā meaning 'a

\footnotetext{
${ }^{46}$ Allah mentions in the Qur'an three ways of revelation: "It is not fitting for a man that Allah should speak to him except by inspiration or from behind a veil or by sending of a messenger to reveal, with Allah's permission, what He wills, for He is Most High, Most Wise". See Surah al-Shūrā 42:51.

${ }^{47}$ Surah al-Muzzammil, 73:5.
} 
weighty word' is referred to the Qur'an itself. ${ }^{48}$ Its descriptiveness as thaqi $\bar{i}$ a may confirm the assertion that the Prophet (p.b.u.h) used to receive the revelation of the Qur'an in hard conditions. Ibn 'Ashūr seems to have taken this position as he said:

"The verse: "We shall, indeed, send down to you a weighty word" indicates that its hardship is pertaining to the Messenger of Allah... its receiving from the one who reveals it to him was hard and difficult." ${ }^{49}$

Further, Ibn Khaldūn argued that ${ }^{50}$ :

"It should be known that, in general, the state of revelation presents difficulties and pains... this is the reason for his (Prophet's) well-known remoteness... and choking (feeling) when in that condition of which the Prophet used to speak. The reason, as we already established, is that revelation means leaving one's humanity, in order to attain angelic perceptions and to hear the speech of the soul. This causes pain since it means that an essence leaves its own essence and exchanges its own stage for the ultimate stage (of the angels). This is the meaning of the choking feeling which Muhammad referred to in connection with the beginning of revelation in his statement: "And he (Gabriel) choked me until it became too much for me; then he released me. Then he said, 'Read,' and I replied, 'I cannot read.' He did this a second and a third time, as the tradition tells."

48 Muhammad al-Ṭāhir ibn 'Ashūr, al-Tahrīir wa al-Tanwīr, vol. 29 (Tunis: al-Dār al-Tunīsiyyah li al-Nashr, 1984), 261.

${ }^{49}$ Ibid.

50 'Abd al-Raḥmān ibn Muhammad ibn Khaldūn, The Muqaddimah, trans. Franz Rosenthal (New York: Bollingen Foundation Inc. 1967), 140-41. 
According to Ibn Khaldūn's above statement, the revelation is not an ordinary phenomenon. It is a departure from one's human nature, or exchanging one's nature for that of angels in order to arrive at angelic perceptions and to hear the soul's speech. It is, in the other word, an interaction with angelic world. This condition therefore must cause pain, and the person connected with such a condition must also experience such pain. However, without unnecessary detail, the foregoing discussion may clearly confirm that the Prophet (p.b.u.h) used to experience some hardship while receiving the revelation of the Qur'an. If, as a result of his interaction with the angelic realm, the Prophet (p.b.u.h) would experience some hardship, what would be the difficulty in the change of his mode during such an interaction?

A tradition narrated by ' $\bar{A}$ 'ishah may support the above discussion. In a long narration pertaining to hädithah al-ifk, the lie against her, she said ${ }^{51}$ :

"... then he felt the burden which he used to feel at the time of receiving the revelation. He began to perspire because of the burden of Allah's words as they descended upon him, and even during the winter season there fell the drops of his sweat like silvery beads..."

Furthermore, a considerable number of traditions outline the Prophet's physical conditions during reception of the revelation. ' $\overline{\mathrm{A}}$ 'ishah narrated that al-Hārith ibn Hishām asked the messenger of Allah, "O Messenger of Allah! How does the revelation come to you?" The Messenger of Allah replied, "Sometimes it comes to me like the ringing of a bell, and it is the hardest of all. Then this state would pass off while I would grasp what is

${ }^{51}$ Muslim ibn al-Hajjāj, al-Musnad al-Ṣaḥiḥ al-Mukhtaṣar bi Naql al'Adl ilā 'an al- 'Adl ila Rasūlillāh 'alayh wa Sallam (Beirut: Dār alTurāth al-'Arabì, n.d), hadith no. 2770. 
inspired. Sometimes, the angel comes to me in the form of a man and talks to me and I memorize whatever he says".

' $\bar{A}$ 'ishah added, indeed I saw the Prophet (p.b.u.h) being inspired in a very cold day, and as the inspiration was over, the sweat was dropping from his forehead". ${ }^{52} \mathrm{Ibn}$ Hajar explained that the ' $\bar{A}$ 'ishah's saying, "In a very cold day" indicates the tendency of experiencing hardship and pain during the revelation because of its mismatch with the human nature. Too much perspiration in a very cold (day) informs of the existence of something extrinsic and additional to the human nature. ${ }^{53}$

A tradition recorded by al-Bukhāri points out that the Prophet's weight used to increase during the revelation. Zayd ibn Thābit narrated that:

"...So, Allah revealed to His Messenger (p.b.u.h) while his thigh was on my thigh, and his thigh became too heavy that I was afraid it might fracture my thigh..." 54

Another tradition points out that his face used to change during the revelation. 'Ubādah ibn al-Ṣāmit narrated that:

"When the revelation descended upon the Messenger of Allah (p.b.u.h), he felt a burden on that account and the colour of his face changed". 55

52 Muhammad ibn Ismā‘ỉl al-Bukhārì, al-Jāmi ‘ al-Musnad al-Șahịh alMukhtașar min Umūr Rasūl Allāh Șalla Allāh 'Alayh wa Sallam wa Sunanih wa Ayyāmih (n.p: Dār Țawq al-Najāḥ, 1422AH), hadith no. 2.

53 Ibn Hajar al-'Asqalāni, Fath al-Bārī Sharh Saḥịh al-Bukhārī, vol. 1 (Berut: Dār al-Ma'rifah, 1379 A.H), 21.

${ }^{54}$ Al-Bukhārī, al-Jāmi ‘ al-Musnad al-Ṣaḥiḥ, 4592.

${ }^{55}$ Muslim, Sahị Muslim, hadith no. 2334. 
'Ubādah ibn al-Șāmit narrated another hadith which shows that the Prophet (p.b.u.h) used to turn his head down when receiving the revelation. He narrated:

"When the revelation descended upon the Messenger of Allah (p.b.u.h), he turned his head down so his companions turned theirs down, and when it was over, he raised his head." ${ }^{56}$

Another narration shows that the Prophet (p.b.u.h) used to snore while receiving the revelation. Safwān ibn Ya' lā ibn Umayyah narrated from his father who said:

"A man came to the Prophet (p.b.u.h) while he was at Ji'ranah, and he was wearing a cloak which had traces of khalūq or sufrah (both are kinds of perfume). He then asked, "(O Prophet!) What do you order me to perform in my 'umrah? So, Allah revealed to his Prophet (p.b.u.h), and he was covered by a piece of cloth. I desired to witness the Prophet (p.b.u.h) while being inspired. Then 'Umar said (to me), "Come! Will you be pleased to see the Prophet (p.b.u.h) while being inspired? I replied in affirmative. 'Umar lifted one corner of the cloth and (there) I saw the Prophet (p.b.u.h) snoring, (The narrator said) I thought he (the one who informed me) said, "The snoring was like that of a camel..." ${ }_{57}$

\section{Were Those Experiences Epileptic Fits?}

As has been pointed out earlier, what the Prophet experienced during the revelation was as a result of the weightiness of Allah's words. Abū Shāmah, while commenting on 'A 'ishah's aforementioned hadith on the Prophet's perspiration during the reception of the

56 Ibid., hadith no. 2335.

${ }^{57}$ Al-Bukhārī, Saḥị̣ al-Bukhārì, hadith no. 1789. 
revelation, argued that the sweat which the Prophet (p.b.u.h) used to produce, the redness of his face, snoring and increase of his weight were (all) as a result of the weightiness of the revelation as Allah already informed right from the beginning of his mission, "We shall, indeed, send down to you a weighty word". 58 Whosoever, therefore, claims anything contrary to this, he must bring clear and untwisted evidences.

If, however, Prophet Muhammad's experiences during the revelation are considered to be the signs of epilepsy, as suggested by Margoliouth, some of the biblical prophets would also face such a charge since, as found in the Bible, they also had some similar experiences. Daniel for example, asserted that:

"And I Daniel alone saw the vision: for the men that were with me saw not the vision, but a great quaking fell upon them, and they fled to hide themselves. So, I was left alone, and saw this great vision, and no strength was left in me; my radiant appearance was fearfully changed, and I retained no strength. Then I heard the sound of his words; and when I heard the sound of his words, I fell on my face in a deep sleep with my face to the ground." 59

Moreover, this same Daniel informed that, he feared and shivered while having the vision. He said:

"While he was speaking this word to me, I stood up trembling. Then he said to me, "Fear not, Daniel, for the first day you set your mind to

\footnotetext{
58 'Abd al-Raḥmān ibn Ismā'īl, Abū Shāmah, Sharh al-Hadìth alMuqtafa fī Mab'ath al-Nabì al-Muștafā (Sharjah: Maktabah alUmarayn al-'Ilmiyyah, 1999), 73-74. https://www.biblegateway.com/passage/?search=Daniel $+10 \% 3 \mathrm{~A} 7$ 9\&version=NIV
} 
Akilu Aliyu \& Adibah, "The Remnant of Medieval Christian Attitudes Towards Prophet Muhammad," Afkār Vol. 21 Issue 2 (2019): 141-174

understand and humble yourself before your God."60

He was also reported to have mentioned that he experienced trouble, anxiety worries, and also retained no strength. He said:

"Then I opened my mouth and spoke. I said to him who stood before me, "O my Lord, by reason of the vision pains has come upon me, and I retain no strength. How can my Lord's servant talk with my Lord? For now, no strength remains in me, and no breath is left in me". ${ }^{61}$

These worries and troubles were similar to those which the Prophet (p.b.u.h) used to experience during his reception of the revelation. And they were the reasons of change of his mode as has been discussed earlier. If, therefore, the Prophet (p.b.u.h) is considered to be epileptic by the Orientalists and Christian missionaries on the ground that his attitudes used to change during the revelation, then Daniel, a biblical Prophet, must also face the same charge since he experienced the same troubles which the Prophet (p.b.u.h) used to experience during the reception of revelation. But we hear none among the Christian scholars who charged him of what they charged the Prophet (p.b.u.h). Jeremiah also while giving an account on his vision narrates:

"My heart is broken within me, all my bones shake; I am like a drunken man, like a man

\footnotetext{
60 Daniel, 10:11-12, Bible Gateway, https://www.biblegateway.com/passage/?search=Daniel+10\%3A11$12 \&$ version $=$ NIV

61 Daniel, 10:16-17, Bible Gateway, https://www.biblegateway.com/passage/?search=Daniel+10\%3A16$17 \&$ version $=\mathrm{KJV}$
} 
overcome by wine, because of the Lord, and because of his holy words." 62

However, Margoliouth's claim may also be falsified on the basis that it is inconsistent with the historical events. It is found in the history that epilepsy was well known to Arabs. They could differentiate it from other sicknesses. ${ }^{63}$ Although they were bitter enemies to the Prophet (p.b.u.h) since before the Christians started demonstrating their animosity, we have not a single historical record in which the Arabs charged him of being epileptic. If he was indeed epileptic, they would have been the first people to seize this opportunity and discredit his revelation on that ground. The absence of such a record may cast doubt in the minds of Margoliouth's readers pertaining to his claim.

Nonetheless, as regard to the claim that the Prophet (p.b.u.h) used to be unconscious during the revelation, the readers of his biography will find it inaccurate. ' $\bar{A}$ 'ishah ibn Abì 'Ațā' narrated that ${ }^{64}$ :

"Sawdah (one of the Prophet's wives) went out to answer the call of nature after the veil was made obligatory. She was a fat lady who could

\footnotetext{
$62 \quad$ Jeremiah, 23:9, Bible Gateway, https://www.biblegateway.com/passage/?search=Jeremiah+23\%3A9 \&version=NIV

${ }^{63}$ In a tradition narrated by 'Ațā' ibn Abì Rabah he said, Ibn 'Abbās said to me: "Should I show you a woman of the people of paradise?" I replied in affirmative. He said: "This black woman came to the Prophet (p.b.u.h) and said: "I am attacked by epilepsy and my body becomes uncovered, so pray Allah for me." The Prophet said (to her): "If you wish you should be patient and enter paradise (as a result of it); and if you wish, I will ask Allah to cure you". She said: "I will be patient," and requested: "But I become uncovered, so please pray Allah for me that I may not become uncovered. So, he (the Prophet) accepted her request and prayed for her. See al-Bukhāri, Sahīh alBukhāri, hadith no. 5652. This tradition clearly confirms that epilepsy was well-known before and during the lifetime of the Prophet (p.b.u.h).

${ }^{64}$ Al-Bukhārī, Șahịh al-Bukhārī, hadith no. 4795.
} 
not hide (her identity) from whoever knew her. So, when 'Umar saw her, he said, "O Sawdah! I swear by Allah, you cannot hide yourself from us, so think of another way that you should not be recognized on going out. Hence Sawdah returned while the Prophet (p.b.u.h) was at my house taking his dinner, and in his hand, there was a bone covered with meat. She entered (into my house) and narrated (to the Prophet), "O Messenger of Allah! I went out to answer the call of nature and "Umar said to me so-and-so". Then Allah revealed to him, and when it was over, the bone was still in his hand as he did not put it down. He said (to Sawdah), "You (women) have been allowed to go out for your needs".

The above tradition therefore may evidently indicate that the Prophet (p.b.u.h) used to receive the revelation in his consciousness. There was not a single historical event in the Muslim data in which the Prophet (p.b.u.h) was found to be unconscious during or after the revelation. The orientalists, although vehemently argued that he used to be unconscious, are yet to produce any accurate historical event to support that assertion.

Moreover, it has not been found in the history of epilepsy any account that the patient remembered what he did or what happened to him during his seizure, but the Prophet (p.b.u.h) used to remember the verses which were revealed to him. If he, indeed, suffered from epilepsy as concluded by Margoliouth, he would not have been able to remember a single verse revealed to him. The fact that he used to remember not only a single verse but even in some cases a whole chapter, may lead to casting some doubt in such a theory.

Again, in the history of epileptic patients before and after the Prophet (p.b.u.h), no one produced a single chapter 
similar to that of the Qur'an or even just a wise saying with which he was hailed as a hero. If the epilepsy therefore has the power to make its victims capable of producing such a sublime book like the Qur' an or any other wise saying, why then only Prophet Muhammad (p.b.u.h) could do that?

Further, Margoliouth's attempt to connect the Prophet's condition during the revelation with a hallucinatory vision which an epileptic goes through could also be viewed as invalid. If the Prophet's annals are seriously investigated, it can be clear that throughout his life there was not any historical event in which he thought that an absent person was with him because of mental disturbance. Whosoever claims such a happening must bring an accurate and authentic historical datum, or otherwise, he will be charged of partiality. Based on this therefore, since Margoliouth's conclusion pertaining to this issue is not supported by any fact, it can never be accepted as a rational and scientific conclusion.

Also, Margoliouth's attempt to connect the Prophet's perspiration during the revelation with that of epilepsy victim is illogical. ' $\bar{A}$ 'ishah's previous tradition on the Prophet's perspiration during the reception of the revelation clearly indicates that, that particular form of revelation was the hardest for him. As can be inferred, that perspiration has already been explained by that tradition, and also justified by such a hardship without which he would not have perspired. Therefore, since there is no source of that information except this Islamic datum, and the perspiration has been justified by the hardship of revelation in this same datum, considering it to be otherwise must be charged as an attempt to change the meaning of what the text embodies.

However, another amusing and unscientific attempt found in Margoliouth's writing, is his struggle to forcefully connect the Prophet's condition during the revelation with the condition of epilepsy victim when "foaming at the 
mouth" ${ }^{65}$ The reader of the Prophet's biography may argue that there is no any historical record which shows that the Prophet (p.b.u.h) used to produce bubbles or foam from his mouth during the revelation, and therefore Margoliouth's suggestion is inaccurate.

It is also surprising how and where Margoliouth found that the Prophet (p.b.u.h) used to turn his head to one side or experience headache during receiving the revelation. ${ }^{66}$ Of course, it was found that the Prophet 'nakasa ra'sah' meaning 'he bowed or bent or turned his head down', not to one side, when the revelation came to him, and also his companions did the same, and when it was over, he raised his head. ${ }^{67}$ The phrase 'rafa 'a ra'sah' meaning 'he raised his head upwards', which is found in the tradition, is a clear indication that he bowed or turned his head down, not to one side as suggested by Margoliouth. And the fact that the companions did the same can nullify the assertion that he was epileptic since no thoughtful man will ever suggest that all those companions who were with him at that time were also epileptics.

Moreover, it is found in the Bible that some Prophets did not only turn down their faces during their visions but also fell on their faces. In Genesis for example, it was mentioned that:

"When Abram was ninety-nine years old the Lord appeared to Abram, and said to him, "I am God Almighty; walk before me, and be blameless. And I will make my covenant between me and you and will multiply you exceedingly." Then Abram fell on his face." 68

\footnotetext{
${ }^{65}$ Margoliouth, Mohammed and the Rise, 46.

${ }^{66} \mathrm{Ibid}$.

${ }^{67}$ Al-Bukhārī, Saḥịh al-Bukhārī, hadith no. 2335.

68

Genesis

17:3,

Bible

Gateway, https://www.biblegateway.com/passage/?search $=$ Genesis $+17 \% 3 \mathrm{~A} 3-$ $8 \&$ version $=$ NIV
} 
Ezekiel also confessed that ${ }^{69}$ :

"Such was the appearance of the likeness of the glory of the Lord. And when I saw it, I fell upon my face, and I heard the voice of one speaking.

If, however, these verses are to be treated in the same manner, will it not be concluded that the Bible contains some epileptic symptoms which are found in some biblical Prophets?

To conclude with, Prophet Muhammad (p.b.u.h) never experienced epilepsy, and even some non-Muslim writers confessed this reality. W. M. Watt for example writes:

"Opponents of Islam have often asserted that Muhammad had epilepsy, and therefore his religious experiences had no validity. As a matter of fact, the symptoms described are not identical with those of epilepsy, since the disease leads to physical and mental degeneration, whereas Muhammad was in the fullest possession of his faculties to the very end. But even if the allegation were true, the argument would be completely unsound and based on mere ignorance and prejudice; such physical concomitants neither validate nor invalidate religious experience." ${ }^{\prime} 0$

An Indian Professor, T. L. Vaswani, even though he is not a Muslim, is surprised and therefore writes:

"Again, and again he (Muhammad) has the 'fits'; the pressure of the unseen is upon him; and his trembling lips uttered the eloquent wisdom recorded in the Qur'an. Yet one

\footnotetext{
69 Ezekiel 1:28, Bible Gateway, https://www.biblegateway.com/passage/?search=Ezekiel+1\%3A28\& version $=\mathrm{NIV}$

70 William Montgomery Watt, Muhammad at Mecca (Oxford: Oxford University Press, 1953), 57.
} 
Akilu Aliyu \& Adibah, "The Remnant of Medieval Christian Attitudes Towards Prophet Muhammad," Afkār Vol. 21 Issue 2 (2019): 141-174

European critic -Sprenger, speaks of Muhamad's 'fits' as 'epilepsy'! Carlyle has better understanding of Muhamad when he speaks of him as the type of the heroic Prophet. Muhamad was a hero and a Prophet..." 71

Edward Gibbon in his discussion on the death of Prophet Muhammad (p.b.u.h) seemed to have felt disappointed by the description of Muhammad (p.b.u.h) as an epileptic. He therefore lamented and observed that:

"His (Prophet's) epileptic fits, an absurd calumny of the Greeks, would be an object of pity rather than abhorrence." 72

His describing it as "an absurd calumny of the Greeks" shows his unhappiness with it.

In his edition of the Gibbon's aforementioned book, J. B. Bury, another Christian unbiased scholar, also pointed out:

"The epilepsy, or falling-sickness, of Mahomet is asserted by Theophanes, Zonaras, and the rest of the Greeks; and is greedily swallowed by the gross bigotry of Hottinger, (Hist. Orient. p. 10, 11), Prideaux, (Life of Mahomet, p. 12,), and Maracci, (tom. ii. Alcoran, p. 762, 763). The titles (the wrapped-up, the covered) of two chapters of the Koran, $(73,74)$ can hardly be strained to such an interpretation; the silence, the ignorance of the Mahometan commentators, is more conclusive than the most peremptory denial; and the charitable side is espoused by Ockley, (Hist. of the Saracens, tom. i. p. 301,)

71 T. L. Vaswani, "I salute Mohamad," Islamic Review, vol. 11, no. 8 (August, 1923), 275-276.

72 Edward Gibbon, The Decline and Fall of the Roman Empire, ed. J. B. Bury, vol. 5 (London: Methuen \& Co. Ltd, $5^{\text {th }}$ edition, 1887), 373. 
Gagnier, (ad Abulfedam, p. 9. Vie de Mahomet, tom. i. p. 118,), and Sale (Koran, p. 469 474). ${ }^{\prime} 73$

Moreover, another great Christian scholar, John Davenport, also rejected this claim and argued:

"What was the real character of Mohammed's ecstatic periods; whether they were simply reveries of profound meditation, or swoons connected with a morbid excitability of the mental or physical constitution, it would be difficult to determine... The assertion, so often repeated, that Mohammed was subject to epileptic fits, is a base invention of the Greeks, who would seem to impute that morbid affection to the apostle of a novel creed as a stain upon his moral character deserving the reprobation and abhorrence of the Christian world. Surely, those malignant bigots might have reflected that if Mohammed had really been afflicted with that dreadful malady Christian charity ought to have commanded them to pity his misfortune rather than rejoice over it, or affect to regard it in the light of a sign of Divine wrath." ${ }^{7}$

\section{Conclusion}

In the previous discussion, Margoliouth's view on pathological theory has been clearly pointed out. Its implication, as has been pointed out, is that Prophet Muhammad (p.b.u.h) was not mentally sound. This is very damaging to his Prophethood and to the revelation he claimed to have brought from God. However, it has been

${ }^{73}$ Ibid., note 161 .

74 John Davenport, An Apology for Mohammed and the Koran (London: J. Davy and Sons, 1869), 14. 
evaluated that his physical experiences during the revelation were not epileptic fits, and that their root course was the weightiness of Allah's words.

In addition, not only the Prophet (p.b.u.h) that came across such an experience while having his vision, even the biblical Prophets were said to have come across it while having their visions. If he, therefore, was alleged to be epileptic on that basis, those biblical Prophets must also face such a charge which, we believe, the Christians will never concur with.

\section{References}

Abū Shāmah, 'Abd al-Raḥmān ibn Ismā‘īl. Sharh al-Hadìth al-Muqtafa fi Mab'ath al-Nabì al-Muștafā. Sharjah: Maktabah al-Umarayn al-'Ilmiyyah, 1999.

Ali, A. Al-Qur'an: A Contemporary Translation. New Jersey: Princeton University Press, 2001.

Ali, A. Y. The Holy Qur'an: Text, Translation and Commentary. Beirut: Dar al-'Arabiyyah, 1938.

Ansari, K. Humayun. "British Historical Imaginations: Rethinking Orientalism?" In Orientalism Revisited: Art, Land and Voyage, ed. Ian Richard Netton. New York: Routledge, 2013: 3-32.

Al-'Asqalāni, Ibn Hajar. Fath al-Bārī Sharh Saḥiḥ alBukhārī, vol. 1. Berut: Dār al-Ma'rifah, 1379AH.

Al-Bukhārī, Muhammad ibn Ismā‘ìil. Al-Jāmi ‘ al-Musnad al-Ṣahịh al-Mukhtașar min Umūr Rasūl Allāh Ṣalla Allāh 'Alayh wa Sallam wa Sunanih wa Ayyāmih. n.p: Dār Ṭawq al-Najāh, 1422AH.

Claassens, Geert H. M. "Jacob Van Maerlant on Muhammad and Islam." In The Medieval Christian Perceptions of Islam, ed. by John Victor Tolan. New York: Garland Publishing, Inc. 1996.

Davenport, John. An Apology for Mohammed and the Koran. London: J. Davy and Sons, 1869. 
Gibb, H. A. R, "Obituary Notice David Samuel Margoliouth", Journal of the Royal Asiatic Society, vol. 72 no. 4 (July 1940): 392-394.

Gibbon, Edward. The Decline and Fall of the Roman Empire, ed. J. B. Bury, vol. 5. London: Methuen \& Co. Ltd, $5^{\text {th }}$ edition, 1887.

Ibn 'Ashūr, Muḥammad al-Ṭāhir. Al-Tahrīir wa al-Tanwīr, vol. 29. Tunis: al-Dār al-Tunisiyyah li al-Nashr, 1984. Ibn Khaldūn, 'Abd al-Raḥmān ibn Muḥammad. The Muqaddimah, trans. Franz Rosenthal. New York: Bollingen Foundation Inc. 1967.

Jeffery, Arthur, "David Samuel Margoliouth", The Muslim World, vol. 30 no. 3 (1940).

Margoliouth, David Samuel, "The Origins of Arabic Poetry," The Journal of the Royal Asiatic Society, vol. 57 no. 3 (1925): 417-449.

Margoliouth, David Samuel. Mohammed and the Rise of Islam. New Delhi: Cosmo Publications, 2011.

Matthew, H. C. G. and Harrison, Brian, ed. Oxford Dictionary of National Biography, vol. 36. Oxford: Oxford University Press, 2004.

Merriam Webster. Webster's New Biographical Dictionary. Massachussets: Merriam Webster, 1988.

Muslim ibn al-Hajjāj. Al-Musnad al-Șahịh al-Mukhtașar bi Naql al-'Adl ilā 'an al-'Adl ilā Rasūlillāh 'alayh wa Sallam. Beyrut: Dār al-Turāth al-'Arabi, n.d.

Quinn, Frederick. The Sum of All Heresies: The Image of Islam in Western Thought. Oxford: Oxford University Press, 2007.

Reeves, Minou. Muhammad in Europe. New York: New York University Press, 2003.

Reif, Stefan C. A Jewish Archive from Old Cairo: The History of Cambridge University's Genizah Collection. New York: Routledge, 2000. 
Akilu Aliyu \& Adibah, "The Remnant of Medieval Christian Attitudes Towards Prophet Muhammad," Afkār Vol. 21 Issue 2 (2019): 141-174

Schmitz, Bettina. "Epilepsy." In The Encyclopaedia of Human Brain, ed. V.S. Ramachandram. New York: Academic Press, 2002.

Sprenger, A. Life of Mohammad from Original Sources. Allahabad: Presbyterian Mission Press, 1851.

The Concise Dictionary of National Biography from Earliest Time to 1985, vol. 11. Oxford: Oxford University Press, 1997.

Ullendorff, Edward. "Alfred Felix London Beeston". In $A$ Century of British Orientalists 1902-2001, ed. Bosworth, C. Edmund. New York: Oxford University Press, 2001.

Vaswani, T. L. "I salute Mohamad," Islamic Review, vol. 11 no. 8 (August, 1923): 275-276.

Watt, William Montgomery. Muhammad at Mecca. Oxford: Oxford University Press, 1953. 
Akilu Aliyu \& Adibah, "The Remnant of Medieval Christian Attitudes Towards Prophet Muhammad," Afkār Vol. 21 Issue 2 (2019): 141-174 